\title{
Die effekte van melatonien op molekulêre vlak
}

\author{
M. Haag* en J.J. Theron \\ Departement Fisiologie, Universiteit van Pretoria, Posbus 2034, Pretoria 0001
}

Ontvang 29 Julie 1991; aunvaar 9 Oktober 1991

\section{UITTRFKSEL}

Die indoolhormoon melatonien word volgens 'n bifasiese sirkadiese ritme deur die pineaalklier afgeskei. Hierdie oorsigartikel bied ' $n$ opsomming van onlangse resultate oor:

(i) faktore wat melatoniensekresie beïnvloed;

(ii) die bestaan van melatonienreseptore in breinweefsel;

(iii) effekte van melatonien as ' $n$ moduleerder van dopaminergiese, noradrenergiese, GABA-ergiese en opiö̈edergiese neurooordragsprosesse;

(iv) die invloed van melatonien op elektriese aktiwiteit en metaboliese snelheid van sekere breinkerne; asook

(v) melatonieneffekte op hormoonafskeiding in die hipotalamus-hipofise-as.

'n Grondliggende meganisme van melatonienwerking deur middel van sikliese nukleotiede en proteienfosforilering word verder voorgestel.

\section{ABSTRACT}

The effects of melatonin on a molecular level

The indole hormone melatonin is secreted in a biphasic circadian rhythm by the pineal gland. This review presents a summary of recent results concerning -

(i) factors that influence melatonin synthesis;

(ii) the existence of melatonin receptors in brain tissue;

(iii) the effects of melatonin as a modulator of dopaminergic, noradrenergic, GABAergic and opioidergic neurotransmitter processes;

(iv) the influence of melatonin on the electric activity and metabolic rate of certain brain nuclei; and

(v) melatonin effects on hormone secretion in the hypothalamic-pituitary axis.

A basic mechanism of melatonin action via cyclic nucleotides and thus protein phosphorylation is presented.

\section{INLEIDING}

Die isolering en karakterisering van die tot nog toe onbekende pineaalhormoon melatonien deur Lerner en medewerkers' in 1958 was die beginpunt van groot vooruitgang in navorsing oor pineaalfunksie. Melatonien

*Outeur aan wie korrespondensie gerig kan word. word volgens 'n bifasiese sirkadiese ritme afgeskei: plasmamelatonienvlakke styg snags en daal bedags baie laag (fig. 1). ${ }^{2}$ Hierdie ritme ontstaan in soogdiere in die suprachiasmatiese kerne (SCK) in die hipotalamus, die primêre "pasaangeërs" vir die meeste sirkadiese ritmes. Hierdie kerne pas ook die ritme by die omgewingsbeligting aan deur middel van die postganglionêre simpatiese 
senuweevoorsiening (fig. 2). ${ }^{3}$ In soogdiere staan die pineaalklier dus met reg bekend as 'n neuroëndokriene herleicr. ${ }^{4}$ In laer diere funksioneer die klier self as 'n outonome, primêre pasaangeër - dit wil sê as 'n fotoëndokriene herleier. ${ }^{5}$
Melatonien word vanaf die essensiële aminosuur, triptofaan, via die neuro-oordragstof, serotonien, gesintetiseer (fig. 3). ${ }^{6}$ Die sintese en vrystelling van die hormoon word beinvloed deur ' $n$ groot verskeidenheid faktore wat in tabel 1 weergegee word.

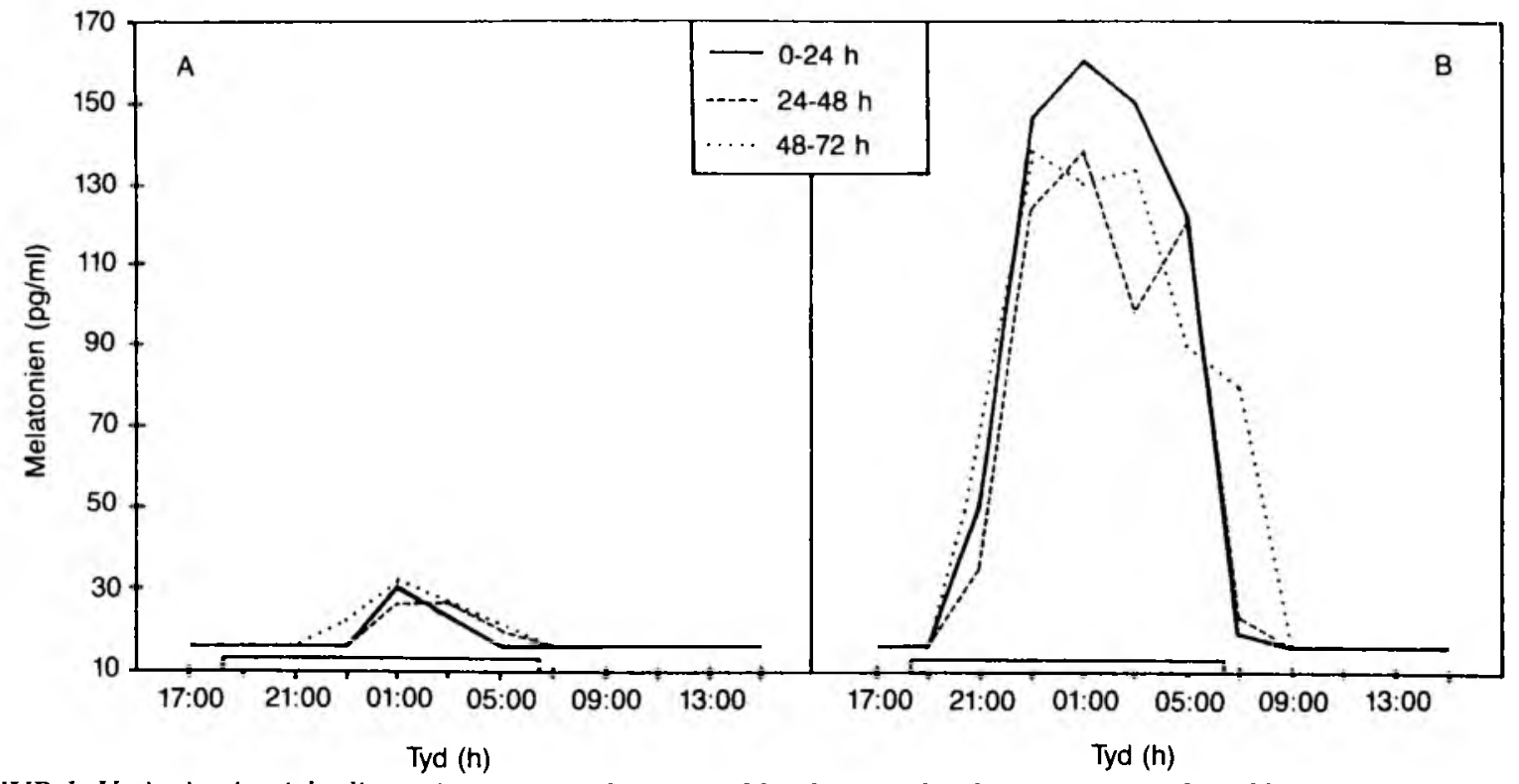

FIGUUR I: Variasies in sirkadiese ritme van melatonienafskeiding. Individu A vertonn relatief lae melatonienpieke in vergelyking met individu B. Aangepas, met toestemming, uit Coetzee et al. ${ }^{2}$

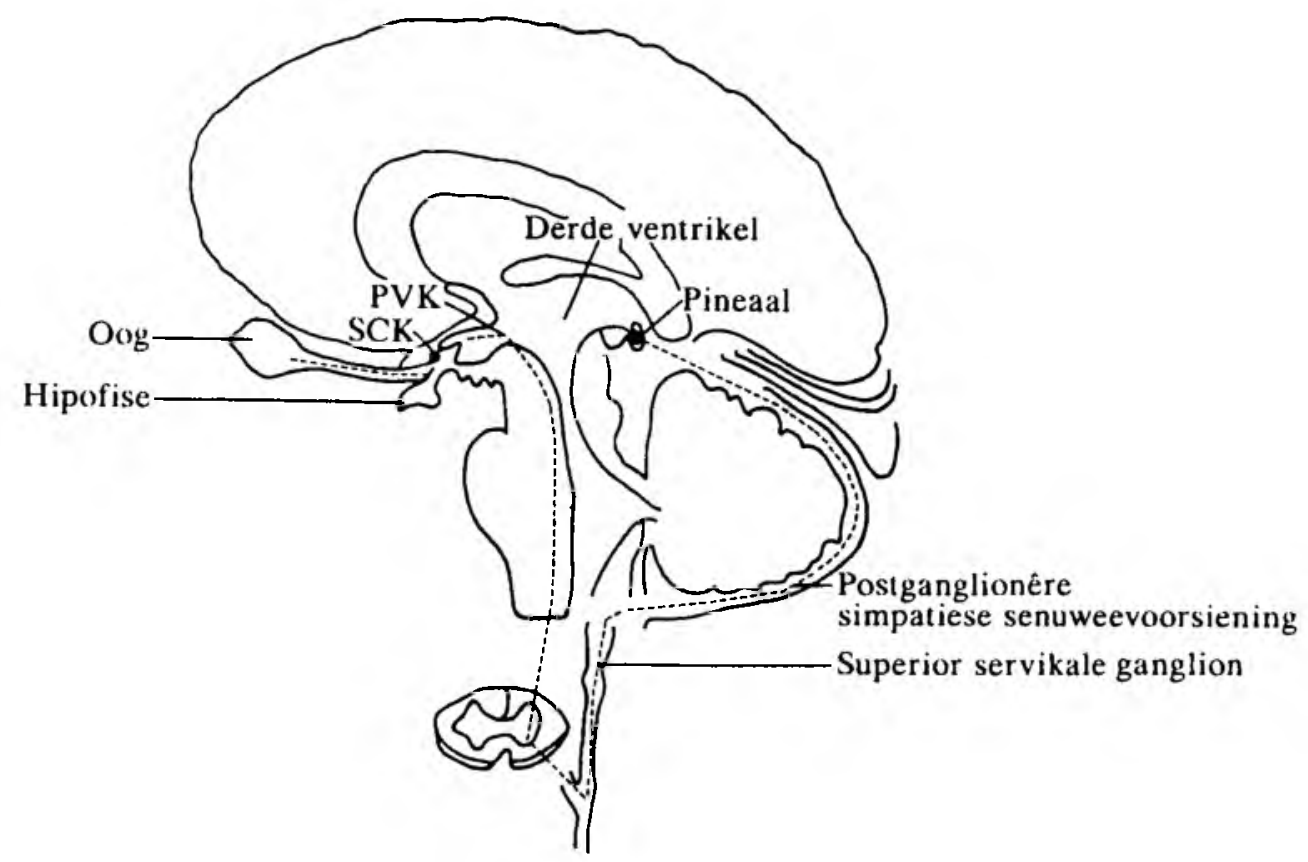

FIGUUR 2: Die anatomiese ligging van die bekende pasaangeërs.

$S C K=$ Suprachiamatiese kerne

$P V K=$ Paraventrikulêre kerne

-..- Verbinding van oog met pineaal

\section{DIE EFFEKTE VAN MELATONIEN}

Aangesien die effekte van melatonien op seisoengebonde voortplantingsgedrag ${ }^{4}$ sowel as antimitotiese ${ }^{36}$ en moontlike antikankermiddel wat liggaamsimmuniteit bevorder, ${ }^{37}$ baie aandag geniet, sal daar in hierdie bespreking nie soveel aandag aan dié aspekte gegee word nie.

\section{MELATONIENRESEPTORE}

Die status van melatonien as óf 'n werklik fisiologies ak- tiewe hormoon, of 'n onaktiewe afbraakproduk van serotonien, is lank bevraagteken. Vir melatonien om as aktiewe hormoon geklassifiseer te word, is die bestaan van melatonienreseptore ' $n$ voorvereiste. In 1979 het Niles en medewerkers $^{38}$ vir die eerste keer die bestaan van melatonienreseptore in die brein beskryf. In hul eksperimente is getritieerde melatonien gebruik wat aanleiding sou kon gee tot niespesifieke binding. Sedertdien is die bestaan van melatonienreseptore herhaaldelik beves- 


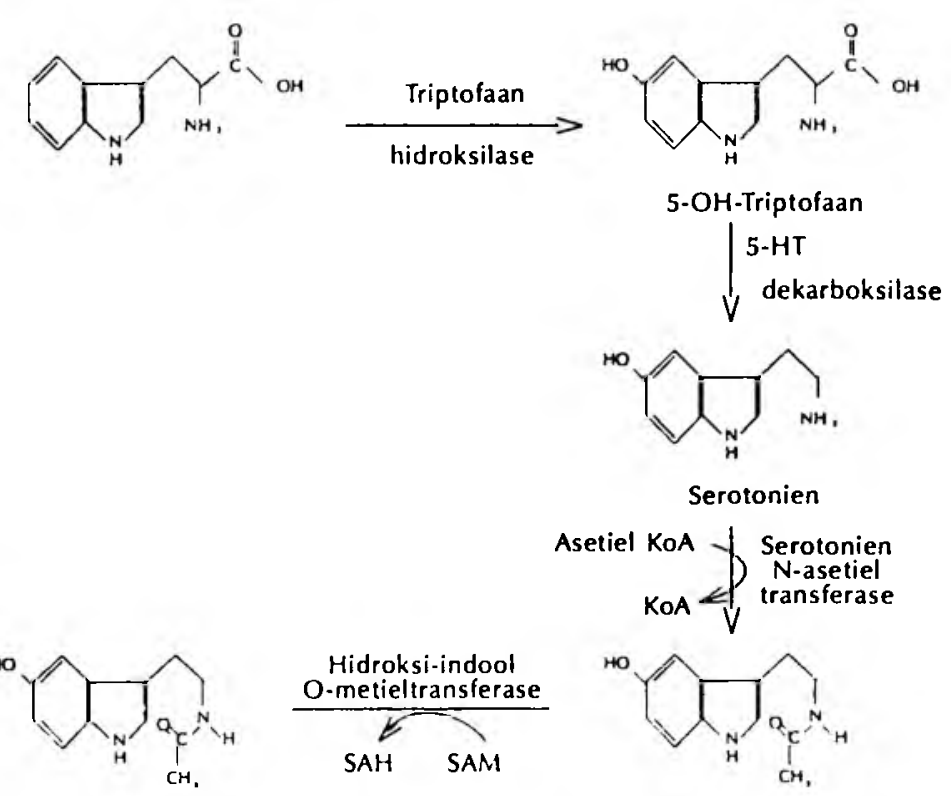

FIGUUR 3: Die sintese van melatonien uit triptofaan.

tig deur die gebruik van ${ }^{125} \mathrm{I}$-melatonien. ${ }^{39,40}$ 'n Sirkadiese ritme van melatonienbinding is in die hipotalamus van mannetjierotte aangetoon ${ }^{41}$ wat afneem met ouderdom. ${ }^{42}$ In wyfierotte neem binding toe in die teenwoordigheid van estrogeen. ${ }^{40.43}$ Outoradiografiese tegnieke het ook 'n sirkadiese ritme in ${ }^{125} \mathrm{I}$-melatonienbinding in die SCK van rotte aangetoon, met 'n piek vroeg soggens en 'n trog 12 uur later. ${ }^{44}$ Dieselfde tipe tegniek het ook reseptore in die SCK van die mens aangetoon..$^{45}$ Die feit dat die ritme van melatonienbinding nie in fase is met die ritme van melatonienvlakke in die plasma nie is indringend deur Reiter in $1987^{46}$ bespreek, wat gelei het tot die sogenaamde “Duration versus Coincidence'-hipotese van melatonienwerking. Die sogenaamde "Coincidence"-hipotese beweer dat melatonien slegs in werking sal tree wanneer sowel die plasmakonsentrasies van die hormoon as die sensitiwiteit van die teikenorgaan 'n kritieke vlak oorskry het. Die "Duration"-hipotese, daarenteen, neem slegs die tydsduur en hoogte van die melatonienpiek, wat deur veranderings in die fotoperiode bepaal word, in aanmerking. In teenstelling met die relatief spesifieke binding van melatonien in die hipotalamus en pars tuberalis van die hipofise van die soogdierbrein, bind ${ }^{125} \mathrm{I}$-melatonien aan verskeie sensoriesbetrokke areas in die kuikenbrein, ${ }^{47}$ wat dui op 'n breër reeks van funksies in dié diere. Benewens in breinweefsel is melatonienreseptore ook al in die retina en pineaal gevind. ${ }^{48}$

\section{MELATONIENEFFEKTE OP SELLULÊRE VLAK: BREINWEEFSEL}

Heelwat uiteenlopende effekte van melatonien op sellulêre vlak is al gedokumenteer. 'n Uitstaande kenmerk van melatonienwerking is dat dit in die meeste gevalle afhanklik is van die sirkadiese tyd van toediening ${ }^{49}$ en dat heeltemal teenoorgestelde effekte dus op verskillende tye verkry kan word.

Een van die ouer hipoteses van melatonienwerking wat veral in die sewentigerjare baie aandag geniet het, is die negatiewe effek van melatonien op die polimerisering van tubulien om mikrotubuli te vorm. ${ }^{50.51}$ Melatonien kan tubulienvlakke in die hipotalamus verlaag en, wanneer dit in millimolare hoeveelhede toegedien word, sommige tubulienafhanklike prosesse in die hipotalamus inhibeer. ${ }^{52}$

TABEL 1

Faktore wat melatoniensekresie beïnvloed

\begin{tabular}{|c|c|c|}
\hline Faktor & $\begin{array}{c}\text { Effek op } \\
\text { melatonien- } \\
\text { sekresie }\end{array}$ & Verwysings \\
\hline Lig & $\downarrow$ & 7,35 \\
\hline$\beta$-adrenergiese stimulasie & $\uparrow$ & 8,29 \\
\hline Isoproterenol ( $\beta$-agonis) & $\uparrow$ & 19 \\
\hline Isoproterenol + etanol & $\uparrow \uparrow$ & 20 \\
\hline Propranolol ( $\beta$-antagonis) & $\uparrow$ & 21 \\
\hline $\mathbf{a}_{2}$-adrenergiese stimulasie & $\downarrow$ & 9,10 \\
\hline Prasosien $\left(\alpha_{1}\right.$-agonis $)$ & $\downarrow$ & 22 \\
\hline $\mathrm{D}_{2}$-dopaminergiese & & \\
\hline stimulasie & $\uparrow$ & 11 \\
\hline MAO-inhibeerders & $\uparrow$ & 24 \\
\hline Stres (bedags) & $\uparrow$ & $12-14$ \\
\hline Stres (snags) & $\downarrow$ & $15-18$ \\
\hline Chloorpromasien & $\downarrow$ & 23 \\
\hline Opioïede & $\uparrow$ & $25-27$ \\
\hline Neuropeptied Y & $\uparrow$ & 28 \\
\hline Prostanoïede & $\uparrow$ & 30 \\
\hline GABA & $\downarrow$ & 31 \\
\hline TSH & $\uparrow$ & 21 \\
\hline LH & $\uparrow$ & 21 \\
\hline FSH & $\downarrow$ & 21 \\
\hline $\mathrm{T}_{3}$ (bedags) & $\uparrow$ & 32 \\
\hline$T_{3}$ (snags) & $\downarrow$ & 32 \\
\hline Estradiol & $\uparrow$ & 21 \\
\hline Testosteroon & $\downarrow$ & 21 \\
\hline Prolaktien & $\uparrow \downarrow$ & 21 \\
\hline Elektromagnetisme & $\uparrow \downarrow$ & $13,33,34$ \\
\hline
\end{tabular}

Die direkte effek van melatonien op enkele ensieme is al beskryf. (i) Monoamienoksidase in die hipotalamus en hipofise kan deur melatonien geïnhibeer word ${ }^{53}$ en kan sodoende breinvlakke van serotonien ${ }^{54}$ en noradrenalien verhoog ${ }^{55}$ - 'n bevinding met heelwat psigiatriese implikasies. (ii) Die inhibisie van siklo-oksigenase in die mediaal-basale hipotalamus van rotte deur melatonien is 
deur Franchi en medewerkers ${ }^{56}$ uit die laboratorium van Cardinali in Buenos Aires aangetoon. Hierdie bevinding plaas melatonien in die posisie van die enigste natuurlike voorkomende anti-inflammatoriese stof met dieselfde werkingswyse as indometasien.

Melatonien word tans algemeen aanvaar as 'n moduleerder van sentrale dopaminergiese, noradrenergiese en GABAergiese neuro-oordragsprosesse: ${ }^{48}$

(i) In vitro-behandeling van hipotalamussinaptosome met melatonien veroorsaak dat dopamienvrystelling verminder word. ${ }^{57}$ Hierdie bevinding is bevestig deur die werk van die navorsingsgroep van Nava Zisapel in Israel: verminderde dopamienvrystelling as gevolg van melatonien word deur die sirkadiese ritme van melatonienreseptorbinding beinvloed ${ }^{58}$ en is verder afhanklik van estrogeen. Ovariëktomie verlaag die inhiberende effek van melatonien op dopamienvrystelling. ${ }^{43}$

(ii) Die vrystelling van neuro-oordragstowwe is afhanklik van kalsium: melatonien kan die opname van ${ }^{45} \mathrm{Ca}^{2+}$ deur sinaptosome onderdruk ${ }^{59}$ en sodoende kalsiumafhanklike prosesse beinvloed.

(iii) Toediening van melatonien in vitro veroorsaak die verhoogde binding van GABA, 'n belangrike inhiberende ncuro-oordragstof aan breinkorteksmembrane. ${ }^{60}$ Ook chroniese toediening in vitro lei tot verhoogde bindingsaktiwiteit in die voorbrein en serebellum. ${ }^{\text {"1 }}$ Omgekeerd het pinealektomie 'n verlaging in GABA-reseptorbinding (afhanklik van die sirkadiese tyd) tot gevolg. ${ }^{62}$

(iv) Serotonienvlakke in verskillende kuikenbreinareas kan ook deur melatonien (wanneer bedags toegedien) verhoog word. ${ }^{63}$ Die interaksie tussen melatonien en serotonien het waarskynlik ook direkte kliniese belang in die psigiatriese veld: ${ }^{64}$ wanneer melatonien in klein dosisse in die nukleus akkumbens van rotte ingespuit word, het dit dieselfde gedragsveranderings as die serotonerge antagoniste metisergied en siproheptadien veroorsaak. Toediening van serotonien sowel as sekere antidepressiewe middels (sowel noradrenerg as serotonerg) kon die effekte van melatonien omkeer. Daar is moontlik 'n gemeenskaplike punt van aksie van serotonien en melatonien in die nukleus akkumbens en die balans tussen die twee stowwe, wat deur antidepressiewe middels gemoduleer kan word, is waarskynlik van funksionele belang. ${ }^{65}$ Hierdie hipotese is verder ondersoek deur Dugovic en Leysen ${ }^{66}$ van die Janssen Navorsingstigting in België wat 'n modulerende invloed van melatonien op die sensitiwiteit van die $5-\mathrm{HT}_{2}$ reseptorbemiddelde slaaprespons aangetoon het.

(v) Die wisselwerking tussen die opioïedsisteem en melatonien is tot op hede nie heeltemal duidelik nie. Sekere opioiede, byvoorbeeld morfien ${ }^{25}$ en des-tyr- $\gamma$ endorfien in rotte ${ }^{2 h}$ sowel as FK-33824 in mense, ${ }^{2 n}$ kan melatoniensekresie verhoog. Hierdie effekte word deur die opioiedblokker naksoloon teengewerk. ${ }^{26.67}$ Melatonien kan op sy beurt plasmavlakke van $\beta$ endorfien verlaag, ${ }^{68}$ terwyl dit 'n stimulerende effek op breinenkefalienvlakke tot gevolg het. ${ }^{69}$ Daar bestaan dus 'n terugvoersisteem tussen die pineaal en die opiö̈edsisteem: die verhouding tussen melatonien en endogene opioiedpeptiede kan moontlik van belang wees in die modulering van verskeie neuroëndokriene funksies. ${ }^{25}$
Soos reeds bespreek, bind melatonien redelik spesifiek aan die SCK in die soogdierbrein. Behalwe bogenoemde effekte op molekulêre vlak, kan melatonien die elektriese aktiwiteit van SCK-neurone, soos gemeet in in vitro elektrofisiologiese eksperimente, inhibeer. ${ }^{70}$ Selfs die metaboliese snelheid (soos gemeet deur 2-deoksiglukose opname en outoradiografiese bepaling daarvan) van die SCK word deur melatonien geinhibeer en wel op spesifieke sirkadiese tye, naamlik 6:00 en 22:00. ${ }^{49}$ Hicrdie meganismes is sekerlik betrokke by die melatonienbemiddelde aanpassing van aktiwiteitsritmes van rotte wat in abnormale lig- of donkertoestande gehou word.

Die effek van melatonien op die hipotalamus-hipofise-as Die endokrinologiese aspekte van melatonienwerking wat voortspruit uit sy aksie op die hipotalamus-hipofise-as lei nog tot baie berigte wat mekaar weerspreek. Slegs enkele aspekte sal hier uitgelig word:

(i) Die invloed van melatonien op die adenohipofisêre hormone is omstrede; sowel aktiverende ${ }^{25.71}$ as inhiberen$\mathrm{de}^{72,73}$ effekte van melatonien op prolaktien, lutropien en tirotropiensekresie is al gerapporteer. 'n Buitengewone reeks eksperimente het gewys dat fetale prolaktiensekresie in skape deur 'n melatonieninplantasie in die ooi onderdruk kan word. ${ }^{74}$ Webley en medewerkers ${ }^{71}$ dui op ' $n$ invloed van geslag op die werking van melatonien - sy groep kon slegs in mans 'n stimulasie van prolaktiensekresie deur melatonientoediening teweegbring. Sommige werkers ${ }^{75 .} 77$ kon egter geen invloed van melatonien op hipofisêre hormone aantoon nie.

(ii) Die pro- sowel as antigonadotrope aspekte van melatonienfunksie lei tot die vermoede dat melatonien sy invloed op die sogenaamde gonadoliberien (GnRH) vanaf die hipotalamus uitoefen. Die vrystelling van gonadoliberien in muise kan moontlik deur melatonien verminder ${ }^{78}$ of tydens puberteit in rotte vertraag word. ${ }^{7 y}$

(iii) Moontlike hipersensitisering sowel as desensitisering van steroiedreseptore in die hipotalamus-hipofise-as deur melatonien is aangetoon. Glass en medewer$\operatorname{kers}^{(k)}$ beweer dat die testosteroonreseptor in die hipotalamus tydens negatiewe terugvoer deur melatonien hipersensitief gemaak word en dat gonadoliberienvrystelling sodoende verminder. Daarenteen dui ander resultate $^{22}{ }^{81}$ op 'n desensiterende effek van melatonien op dic estrogeenreseptor: estrogeengestimuleerde prolaktiensekresie deur die hipofise kan deur melatonien verminder word. MCF-7 kultuurselle se estrogeenreseptore kan ook deur melatonien geblokkeer word. ${ }^{82.83}$ Die inhiberende betrokkenheid van melatonien in die werking van estrogeen op teikenorgaanvlak verduidelik ook moontlik die koppeling van hoë melatonienvlakke met amenoree ${ }^{\text {th }}$ en die verdwyning van die estrussiklus in melatonienbehandelde rotte. ${ }^{85}$

\section{Diverse effekte van melatonien op sekere hormone}

Die sintese van die insulienafhanklike groeifaktor word op 'n geslagspesifieke wyse deur melatonien gestimuleer. ${ }^{82 .}{ }^{40}$ 'n Antagonisme in die werking van melatonien en kortisol is al gepostuleer ${ }^{86.87}$ wat nic altyd ondersteun word nie. ${ }^{88}$ Effekte van melatonien op die sintese van $11-\beta$ hidroksisteroïed-dehidrogenase (inhiberend), 'n ensiem in die steroïedsintesepad, is al aangetoon. ${ }^{91}$ In hierdie ver- 
band is dit interessant dat melatonien (soos ook LH en katesjolamiene), wanneer dit by geaspireerde granulosaselle van die menslike ovarium gevoeg word, progesteroonsintese kan bevorder. ${ }^{92}$

\section{Die basiese werkingsmeganisme van melatonien}

Wanneer al bogenoemde effekte van melatonien in ag geneem word, is dit duidelik dat daar 'n tot nog toe onbekende basiese werkingsmeganisme van melatonien moet wees. So 'n basiese meganisme sou geleë kon wees in die effek van melatonien op sikliese nukleotiede - cAMP-vlakke daal terwyl cGMPvlakke styg. ${ }^{93-95}$ Hierdie meganisme betrek 'n sogenaamde G-proteien van die inhiberende (Gi) tipe. ${ }^{48}$ Hierdie effekte op tweedeboodskappersisteme het waarskynlik veranderings in proteienfosforilering tot gevolg wat die funksie van ioonkanale kan beheer. Deur hierdie meganisme sou sellulêre funksie op 'n grondliggende wyse verander kan word.

\section{LITERATUURVERWYSINGS}

1. Lemer, A.B., Case, J.D., Takahashi, Y., Lee, T.H. \& Mori, W. (1958) Isolation of melatonin, the pineal factor that lightens melanocystes, $J$. Am. Chem. Soc., 80, 25-87.

2. Coetzee, J.A., Theron, J.J. \& Van der Merwe, C. A. (1989). Consecutive melatonin circadian rhythms in normal volunteers, S.A. Med. J., 75, 163-165.

3. Reiter, R.J. (1980). The pineal gland: A regulator of regulators, Prog. Psychobiol. Physiol. Psychol., 9, 323-356.

4. Reiter. R.J. (1983). Pineal gland: An intermediary between the environment and the endocrine system, Psychoneuroendocrinology: 8, 31-40.

5. Underwood, H. (1984). The pineal and circadian rhythms, The pineal gland, 5, 221-251

6. Miles, A. \& Philbrick, D. (1987). Melatonin: Perspectives in laboratory medicine and clinical research, Critical Revs. Clin. Lab. Sci., 25, 231-253.

7. Korf, H.K. \& M $\varnothing l l e r$, M. (1984). The innervation of the mammalian pincal gland with special reference to central pinealopetal projections, Pineal Res. Rev., 2, 41-86.

8. Klein, D.C. \& Weller, J.L. (1970). Indole metabolism in the pineal gland: A circadian rhythm in N-acetyl transferase, Science, 169, 1093-1095.

9. Pratt, B.L. \& Takahashi, J.S. (1987), Alpha-2 adrenergic regulation of melatonin release in chick pineal cell cultures, $J$. Neurosci., 7 , 3665-3674.

10. Pratt, B. L. \& Takahashi, J.S. (1988). A pertussis toxin-sensitive G-protein mediates the alpha-2 adrenergic receptor inhibition of melatonin release in photoreceptive chick pineal cell cultures, Endocrinology: 123, 277-283.

11. Zawilska, J. \& Iuvone, P.M. Catecholamine receptors regulating serotonin- $\mathrm{N}$-acetyltransferase activity and melatonin content of chicken retina and pineal gland: D-2 dopamine receptors in retina and alpha-2 adrenergic receptors in pineal gland, J. Pharm. Exp. Ther. 250, 86-91.

12. Heinzeller, T.H., Joshi, B.M., Nürnberger, F. \& Reiter, R.J. (1988) Effects of aggressive encounters on pineal melatonin formation in male gerbils, J. Comp. Physiol. 164, 91-94.

13. Welker, H.A. \& Vollrath, L. (1984). The effects of a number of shor term exogenous stimuli on pineal serotonin- $\mathrm{N}$-acetyl-transferase activity in rats, J. Neural. Transm., 59, 69-76.

14. Lynch, H.J., Eng, J.P. \& Wurtman, R.J. (1973). Control of pineal indole biosynthesis by changes in sympathetic tone caused by factors other than environmental lighting, Proc. Natl. Acad. Sci. U.S. A., 70, 1704-1707.

15. Morton, D.J., Reiter, R.J. \& Buzzel, G.R. (1989). Swimming-induced suppression of rat pineal melatonin is prevented by treatment with calcium channel blockers (42836), Proc: Soc. Exp. Biol. Med., 190, 105-108.

16. Monteleone, P., Maj, M., Fusco, M., Orazzo, C. \& Kemali, D. (1990). Physical exercise at night blunts the nocturnal increase of plasma melatonin levels in healthy humans, Life Sci. , 47, 1989-1995.

17. Troiani, M.E., Reiter, R.J., Vaughan, M.K., Gonzalez-Brito, A. \& Herbert, D.C. (1988). The depression in rat pineal melatonin production after saline injection at night may be elicited by corticosterone, Brain Res., 450, 18-24.

18. Schröder, H., Reuss, S., Stehle, J. \& Vollrath, L. (1988). Intraarterially administered vasupressin inhibits nocturnal pineal melatonin synthesis in the rat, Comp. Biochem. Physiol., 89A, 651-653.

19. Santana. C., Guerrero, J.M., Reiter, R.J., Puig-Domingo, M. \& Gonzalez-Brito, A. (1988). Stimulatory effect of isoproterenol but not of dibutyryl cyclic AMP of N-acetyltransferase activity and melatonin content of Syrian hamster pineal gland in organ culture. Neuroendocri- nology., 48, 229-234.

20. Chung, C.T., Tamarkin, L., Hoffman, P.L. \& Tabakoff, B. (1988). Ethanol enhancement of sisoproterenol-stimulated melatonin and cyclicAMP release from cultured pineal glands, J. Pharmacol. Exp. Ther., 249, 16-21.

21. Cardinali, D.P., Vacas, M.I., Sarmiento, M.I.K., Etchegoyen, G.S., Pereyra, E.N. \& Chuluyan, H.E. (1987). Neuroendocrine integrative mechanisms in mammalian pineal gland: Effects of steroid and adenohypophysical hormones on melatonin synthesis in vitro, J. Steroid Biochem. , 27, 565-571.

22. Palazidou, E. \& Franey, C. (1989). Evidence for a functional role of alpha-l-adrenoceptors in the regulation of melatonin secretion in man, Psychoneuroendocrinology. 14, 131-135.

23. Beedham, C., Smith, J.A., Steele, D.L. \& Wright, P. A. (1987). Chlorpromazine inhibition of melatonin metatolism, by normal and induced rat liver microsomes, Eur. J. of Drug Metabolism and Pharmacokinetics, 12, 299-302.

24. Murphy, D.L., Garrick, N.A., Hill, H.L. \& Tamarkin, L. (1987). Marked enhancement of clorgyline of nocturnal and daytime melatonin release in rhesus monkeys, Psychopharmacology, 92, 382-384.

25. Esposti, D., Esposti, G., Lissoni, P., Paravicini, L. \& Fraschini, F. (1988). Action of morphine on melatonin release in the rat, J. Pineal Res. 5, 35-39.

26. Gaffori, O., Geffard, M. \& Van Ree, J.M. (1983). Des-tyr gammaendorphin and haloperidol increase pineal melatonin levels in rats, $P$ eptides, 4, 393-395.

27. Lissoni, P., Esposti, G., Mauri, R., Resentini, M., Morabito, F., Fumagalli, P., Santagostino, A., Delitala, G. \& Fraschini, F. (1986). A clinical study of the relationship between the pineal gland and the opioid system, J. Neural. Transm., 65, 63-73.

28. Vacas, M.I., Sarmiento, M.I.K., Pereyra, E.N., Etchegoyen, G.S. \& Cardinali, D.P. (1987). In vitro effect of Neuropeptide Y on Melatonin and Norepinephrine release in rat pineal gland, Cellular and Molecular Neurobiology; 7, 309-315.

29. Cardinali, D.P. \& Vacas, M. I. (1987). Cellular and molecular mechanisms controlling melatonin release by mammalian glands, Cell. $\mathrm{Mol}$. Neurobiol. , 7. 323-337.

30. Vacas, M.I., Keller-Sarmiento, M.I., Etchegoyen, G.S., Pereyra, E.N. Gimeno, M.F. \& Cardinali, D.P. (1987). Involvement of 5-Lipoxygenase pathway in Norepinephrine stimulation of rat pineal Melatonin synthesis, Neuroendocrinol., 46, 412-416.

31. Rosenstein, R.E., Chuluyan, H.E., Pereyra, E.N. \& Cardinali, D.P. (1989). Release and effect of gamma-aminobutyric acid (GABA) on rat pineal melatonin production in vitro, Cell. Mol. Neurobiol. 9, 207-218.

32. Catala, M.D. \& Quay, W.B. (1988). Effects of thyroid hormone on light/dark melatonin synthesis and release by young and maturing rat pineal glands in vitro, Int. J. Devel. Neurosci. , 6, 285-288.

33. Wilson, B.W., Anderson, L.E., Hilton, D.I. \& Phillips, R.D. (1981). Chronic exposure to $60-\mathrm{Hz}$ electric fields: Effects on pineal function in the rat, Binelectromagnetics, 2, 371-380.

34. Stehle, J., Reuss, S., Schroder, H., Henschel, M. \& Vollrath, L. (1988) Magnetic field effects on pineal $\mathrm{N}$-acetyltransferase activity and melatonin content in the Gerbil - role of pigmentation and size, Physiology and Behaviour, 44, 91-94.

35. Moore, R.Y. \& Klein, D.C. (1974). Visual pathways and the central neural control of a circadian rhythm in pineal serotonin $\mathrm{N}$-acetyltransferase activity, Brain Res., 71, 17-33.

36. Sewerynek, E. \& Lewinski, A. (1989). Melatonin inhibits mitotic activity of adrenocortical cells in viw and in organ culture, J. Pineal Res. , 7, 1-12

37. Regelson, W. \& Pierpaoli, W. (1987). Melatonin: A rediscovered antitumour hormone? Its relation to surface receptors, sex steroid hormones, immunologic response and chronobiologic factors in tumour growth and therapy, Cancer Invest., 5, 379-385.

38. Niles, L.P., Wong, Y., Mishra, K.K. \& Brown, G.M. (1979). Melatonin receptors in brain, Eur. J. Pharmacol., 55, 219-220.

39. Duncan, M.J., Takahashi, J.S. \& Dubocovich, M.L. (1986). Characterization of $2-\left[{ }^{125} \mathrm{I}\right]$ iodomelatonin binding sites in hamster brain, Eur. J. Pharmacol., 132, 333-334.

40. Laudon, M. \& Zisapel, N. (1987). Impact of circulating estradiol on melatonin binding sites in discrete areas of the female rat brain, Brain Res., 402, 146-150.

41. Zisapel, N., Nir, I. \& Laudon, M. (1988). Circadian variations in melatonin binding sites in discrete areas of the male rat brain, FEBS. Lett., 1, 172-176.

42. Laudon, M., Nir, I. \& Zisapel, N. (1988). Melatonin receptors in discrete brain areas of the male rat, Neuroendocrinology, , 48, 577-583.

43. Zisapel, N., Shaharabani, M. \& Laudon, M. (1987). Regulation of melatonin's activity in the female rat brain by estradiol: Effects on neurotransmitter release and on iodomelatonin binding sites, Neuroendocrinology, 46, 207-216.

44. Laitinen, J.T., Castren, E., Vakkuri, O. \& Saavedra, J.M. (1989). Diumal 
rhythm ol melatonin binding in the rat suprachiasmatic nucleus, Endocrinology, 124, 1585-1587.

45. Reppert, S.M., Weaver, D.R., Rivkees, S.A. \& Stopa, E.G. (1988) Putative melatonin receptors in a humun biological clock. Science, 242 78-81.

46. Reiter, R.J. (1987). The melatonin message: Duration versus coincidence hypothesis, Life Sci., 40, 2119-2131.

47. Rivkees, S.A., Cassone, V.M., Weaver, D.R. and Repper, S.M. (1989) Melatonin receptors in chick brain: Characterization and Lxcalization, Endocinology, 125, 363-368.

48. Stankov, B. \& Reiter, R.J. (1990). Melatonin receptors: Current status, facts and hypotheses, Life Sci. 46, 971-982.

49. Cassone, V.M., Roberts, M.H. \& Moore, R.Y. (1988). Effects of melatonin on 2-deoxy- $\left[1-{ }^{14} \mathrm{C}\right]$ glucose uptake within rat suprachiasmatic nucleus, Am. J. Physiol., 255, R332-R337.

50. Cardinali, D.P. \& Freire, F. (1975). Melatonin effects on brain. Interaction with microtubular protein, inhibition of fast axoplasmic flow and induction of crystalloid and tubular formations in the hypothalamus, Mol. Cell. Endocrinol. 2, 317-330.

5I. Piezzi, R.S. \& Cavicchia, J.C. (1981). Effects of cold and melatonin on the microtubules of the toad sciatic nerve, Anat. Res. , 200, 115-120.

52. Cardinali, D.P. (1981). Molecular biology of melatonin: Assessment of the "Microtubule hypothesis of melatonin action", Mol. Biol. 247-255.

53. Urry, R.L. \& Ellis L.C. (1975). Monoamine oxidase activity of the hypothalamus and pituitary: alterations after pinealectomy, changes in photoperiod, or addition of melatonin in vitro, Experientia, 31, 891-893

54. Anton-Tay, F., Diaz, J.L., Fernandez-Guardiola, M. (1971). On the effects of melatonin upon human brain: Its possible therapeutic implications, Life Sci., 10, 841-850.

55. Wendel, O.T., Waterbury, L.D. \& Pearce, L.A. (1974). Increase in monoamine concentrations in rat brain following melatonin administration, Experientia, 30, 1167-1168.

56. Franchi, A.M., Gimeno, M.F., Cardinali, D.P. \& Vacas, M.I. (1987). Melatonin, 5-HT and some of their analogs as cyclo-oxygenase inhibitors in rat medial basal hypothalamus, Brain Res., 405, 384-388.

57. Cardinali, D.P., Nagle, C.A. \& Rosner, J.M. (1975). Effects of melatonin on neurotransmitter uptake and release by synaptosome-rich homogenates of the rat hypothalamus, Neumendocrinology, 18, 72-85.

58. Zisapel, N., Egozi, Y. \& Laudon, M. (1985). Circadian variations in the inhibition of dopamine release from adult and new-born rat hypothalamus by melatonin, Neuroendocrinology, 40, 102-108.

59. Vacas, M.I., Keller-Sarmiento, M I I and Cardinali, D.P. (1984). Pineal methoxy indoles depress calcium uptake by rat brain synaptosomes, Brain Res., 294, 166-168.

60. Coloma, F.M. \& Niles, L.P. (1988). Melatonin enhancement of [ $\left.{ }^{3} \mathrm{H}\right]-$ $r$-aminobutyric acid and ${ }^{3} \mathrm{H} \mid$ muscimol binding in rat brain, Biochem Pharmacol, 37, 1271-1274.

61. Niles, L.P., Pickering, D.S. \& Arciszewski, M.A. (1987). Effects of chronic melatonin administration on GABA and diazepam binding in rat brain, J. Neural. Transm., 70, 117-124.

62. Acuna-Castroviejo, D., Rosenstein, R.E., Romeo, H.E. Cardinali, D.P (1986). Changes in gamma-aminobutyric acid high affinity binding to cerebral cortex membranes after pinealectomy or melatonin administration to rats, Neuroendocrinology, 43, 24-31.

63. Cassone, V.M., Lane, R.F. and Menaker, M. (1986). Melatonin-induced increases in serotonin concentrations in specific regions of the chicken brain, Neuroendocrinology, 42, 38-43.

64. Miles, A. \& Philbrick, D. R.S. (1988). Melatonin and Psychiatry, Biol. Psychiarn, 23, 405-425.

65. Gaffori, O. \& Van Ree, J.M. (1985). Serotonin and antidepressant drugs antagonize melatonin-induced behavioural changes after injection into the nucleus accumbens of rats, Neuropharmacology, 24, 237-244.

66. Dugovic, C., Leysen, J.E. \& Wauquier, A. (1989). Melatonin modulates the sensitivity of 5-hydroxytryptamine-2 receptor-mediated sleepwakefulness regulation in the rat, Neurosci. Letters, 104, 320-325.

67. Lowenstein, P.R., Pereyra, E.N., Solveyra, C.G. \& Cardinali, D.P. (1984). Effects of naxolone on the nocturnal rise of rat pineal melatonin content, Eur. J Pharmacol. 98, 261-264.

68. Lissoni, P., Mauri, R., Resentini, M., Morabito, F, Fraschini, F. Fumagalli, P. \& Santagostino, A. (1984). Beta-endorphin levels after melatonin administration in man, J. Steroid Biochem., 20, 1458-1460.

69. Kumar, M.S.A., Chen, C.L., Sharp, D.C., Liu, J.M., Kalra, P.S. \& Kalra, S.P. (1982). Diurnal fluctuations in methionine-enkephalin levels in the hypothalamus and pre-optic area of the male rat: effects of pinealectomy, Neuroendocrinology, 35, 28-33.

70. Mason, R. \& Brooks, A. (1988). The electrophysiological effects of melatonin and a putative melatonin antagonist ( $\mathrm{N}$-acetyltryptamine) on rat suprachiasmatic neurones in vitro, Neurosci. Lett., 95, 296-301.
71. Webley, G.E., Böhle, A. \& Leidenberger, F A. (1988). Positive relationship between the nocturnal concentrations of melatonin and prolactin, and a stimulation of prolactin after melatonin administration in young men, J. Pineal. Res., 5, 19-33.

72. Bartsch, C., Bartsch, H., Fuchs, U., Lippert, T.H., Bellmann, O. \& Gupta, D. (1989). Stage-dependent depression of melatonin in patients with primary breast cancer, Cancer, 64, 426-433.

73. Griffiths, D., Bjøro, T., Gautvik, K. \& Haug, E. (1987). Melatonin reduces the production and secretion of prolactin and growth hormone from rat pituitary cells in culture, Acta Physiol. Scand., 131, 43-49.

74. Serón-Ferré, M., Vergara, M., Parraguez, V.H., Riquelme, R. \& Llanos, A.J. (1989). Fetal prolactin levels respond to a maternal melatonin inplant, Endocrinology, 125, 400-403.

75. Strassman, R.J., Peake, G.T., Qualls, C.R. \& Lisansky, E.J. (1987). A model for the study of the acute effects of melatonin in man, J. Clin. Endocrinol. Metab., 65, 847-852.

76. Sirassman, R.J., Peake. G.T., Qualls, C.R. \& Lisansky, E.J. (1988). Lack of an acute modulatory effect of melatonin on human nocturnal thyrotropin and cortisol secretion, Neuroendocrinol., 48, 387-393.

77. Paccotti, P., Terzolo, M. \& Piovesan, A. (1988). Effects of exogenous melatonin on human pituitary and adrenal secretions. Hormonal responses to specific stimuli after acute administration of different doses at two opposite circadian stages in men, Chronobiologica, 15, 279-288.

78. Glass, J.D. \& Knots, L.K. (1987). A Brain Site for the antigonadal action of melatonin in the white-footed mouse (Peromyscus leucopus): Inwolvement of the immunoreactive GnRH Neuronal System, Neunvendocrinology, 46, 48-55

79. Aubert, M.L., Rivest, R.W., Lang, U., Winiger, B.P. \& Sizonenko, P.C. (1988). Delayed sexual maturation induced by daily melatonin administration eliminates the LH response to naxolone despite normal responsiveness to GnRH in juvenile male rats, Neuroendocrinologv. $48,72-80$

80. Glass, J.D. \& Nolan, P.L. (1988). Melatonin acts in the brain to mediate seasonal steroid inhibition of luteinizing hormone secretion in the white-footed mouse (Peromyscus leucopus), Proc. Soc. Exp. Biol. Med., 188, 375-380.

81. Villanua, M.A., Agrasal, C., Tresguerres, J.A.F., Vaughan, M.K., Esquifino, A.I. (1989). Melatonin effects on prolactin secretion in pituitary-grafted male rats, J. Pineal Res., 6, 33-41

82. Blask, D.E. \& Hill, S.M. (1986). Effects of melatonin on cancer: Studies on MCF-7 human breast cancer cells in culture, J. Neural. Transm. Suppl. 21, 433-449.

83. Hill, S.M. \& Blask, D.E. (1988). Effects of pineal hormone melatonin on the proliferation and morphological characteristics of human breast cancer cells (MCF-7) in culture, Cancer Res., 48, 6121-6126.

84. Brzezinski, A. \& Lynch, H.J. (1988). The circadian rhythm of plasma melatonin during the normal mensirual cycle and in amenorrheic women. J. Clin. Endocrin. Met., 66, 891-895

85. Petterborg, L.J. \& Rudeen, P.K. (1989). Effects of daily afternoon melatonin administration on body weight and thyroid hormones in female hamsters, J. Pineal Res., 6, 367-373.

86. Aoyama, H., Mori, N. \& Mori, W. (1987). Anti-glucocorticoid effects of melatonin on adult rats, Acta Pathol. Jpn., 37, 1143-1148.

87. Bane, M.S., Poland, R.E. \& Whybrow, P.C. (1989). Pituitary-adrenal and thyroid effects on melatonin content of the rat pineal gland, PSychoneuroendocrinology. 14, 165-167.

88. Familari, M. \& Funder, J.W. (1987). Melatonin and glucoconticoid hormones, Jpn. J. Exp. Med., 73-77.

89. Vriend, J., Sheppard, M.S. \& Bala, R.M. (1988). Melatonin increases serum Insulin-like Growth Factor-1 in male Syrian hamsters, Endocrinology, 122, 2558-2561.

90. Vriend, J., Sheppard, M.S. \& Bala, R.M. (1989). Effects of melatonin and hypothyroidism on somatomedin levels of female Syrian hamsters, J. Pineal Res. , 7, 85-90.

91. Touitou, Y., Boghan, A., Auzéby, A.\& Touitou, C. (1989). Activity of melatonin and other pineal indoles on the in vitro synthesis of cortisol, cortisone and adrenal androgens, J. Pineal Res., 6, 341-350.

92. Webley, G.E., Luck, M.R. \& Hearn, J.P. (1988). Stimulation of progesterone secretion by cultured human granulosa cells with melatonin and catecholamines, J. Reprod. Fert., 84, 669-677.

93. Veseley, D.L. (1980). Melatonin enhances guanylate cyclase activity in a variety of tissues, Mol. Cell. Biochem., 35, 55-58.

94. Vacas, M.I. \& Sarmiento, M.I.K (1981). Melatonin increases cGMP and decreases cAMP levels in rat medial basal hypothalamus in vitro, Brain Res., 225, 207-211.

95. Lewiñski, A., Sewerynek, E., Zerek-Meleń G., Kunert-Radek, J., Pawlikowski, M. \& Karasek, E. (1989). Influence of melatonin and $\mathrm{N}$-acetyl-serotonin on the cyclic AMP concentration in rat thyroid lobes incubated in vitro, J. Pineal Res., 7, 55-61. 